\title{
ОНОМАСТИКА ДЕРЕВЕНЬ ДУБРОВСКОГО ПРИХОДА КРИВАНДИНСКОГО СЕЛЬСКОГО ПОСЕЛЕНИЯ
}

\section{Onomastics of Villages in the Dubrovsky Parish of Krivandinsky Rural Settlement}

Keywords: onomatology, dialectology, anthroponymic onomastics, nickname, expedition materials, Moscow region

Contact: МГОУ; markadeev@list.ru

К настоящему времени Московская область, как и вся остальная Россия, с точки зрения диалектологии была исследована лишь фрагментарно. В работах И. И. Ордынского, Н. М. Каринского, В. Н. Сидорова, А. В. Текучева, А. Ф. Войтенко и других ученых выделяются такие районы, как Гвоздня, Гуслица, Гжель, Ялмота, Кусковщина, Тепловщина, Башмачники, Тепличники, Шувалики и др.; населенные места, не входящие в уже обозначенные исследователями группы, как правило, остаются белым пятном на карте диалектолога. Данная работа призвана обратить внимание читателя на Дубровский приход - заповедный уголок Московской области, отраженный лишь в нескольких нелингвистических трудах, в частности - в краеведческой работе В. М. Казакова (Казаков 1995) и в архивном исследовании Н. В. Давыдова (Давыдов 2010). В тексте статьи публикуются материалы полевой экспедиции ноября 2019 года, направленной на сбор ономастики в обозначенном регионе. Данная работа является результатом исследований, проведенных Лабораторией палеолингвистики и региональной лексикографии.

Основная цель данной работы: зафиксировать антропо-ономастическую лексику жителей Дубровского прихода, а также установить происхождение исследуемых единиц.

Под Дубровским приходом понимается группа деревень, объединенная культурно и географически вокруг ныне исчезнувшего села Дуброво, где функционировала Воскресенская церковь и проводились регулярные праздничные ярмарки. В настоящее время Дубровский приход входит в состав Кривандинского сельского поселения Шатурского района, располагающегося на 
востоке Московской области, в регионе, который в разные исторические эпохи принадлежал к числу земель Владимирского уезда и Рязанской губернии. История этого края берет свое начало в XIV-XVI вв., к этому времени относятся первые упоминания о селе Дуброво, а также о ряде населенных пунктов, на тот момент входящих в Дубровскую волость (Давыдов 2010: 85-89), из которых до нашего времени дошли 6: д. Починки, д. Стенинская, д. Митинская, д. Левинская, д. Лешниково и д. Ивановская. Остальные же не сохранились даже в памяти местных жителей, исчезнув навсегда с лица земли и оставшись лишь на страницах исторических документов. Издревле соединенные одной тупиковой дорогой, примыкающей ныне к Шатурскому шоссе, эти населенные места оказались частично изолированы от внешнего мира, минимально испытывая влияние извне, что поспособствовало формированию особого уклада жизни, но также и сохранению культурного кода, проявляющегося в том числе в творчестве антропонимической ономастики. В ходе исследовательской экспедиции в ноябре 2019 года, проведя опрос среди населения д. Лешниково и д. Стенинская, нам удалось собрать ономастический материал, ставший основой данной работы.

Говоря о личных именах в д. Лешниково, стоит отметить важную особенность: все коренные жители деревни имеют одну общую фамилию Ко́новы и осознают свое родство, восстанавливая в памяти общих предков. Все прочие фамилии осознаются как пришлые и четко связываются с тем местом, откуда они пришли. Так известно, что Бу́ховы из Ивановской, Гу́севы из Починок, Ка́рцевы из Дуброво, Песко́вы с Хутора между Стенинской и Починками, Маркаде́евы с Урала и т. д. Такое обилие «чужих» фамилий неслучайно. Возникновение здешней поговорки «Лешниково - деревня невест» объясняется преобладающей рождаемостью девочек над мальчиками. Отсюда и привычка у старшего поколения называть всех девочек невестами. Тем не менее, образование прозвищ от фамилий является непродуктивным в данной местности. Зафиксированы лишь две номинации, образованные подобным образом: Гуси́ - 'от фамилии Гусевы' и Бармаши́ - 'от фамилии Бармашовы'. Примечательно, что в первом случае фамилию принесла женщина, а во втором - мужчина, состоявший до этого в косвенном родстве с Коновыми. Прозвище Бармаши́ха - 'жена Бармаша́ (Бармашова)', имеет в своем морфемном составе суффикс -их-, являющийся формантом для образования имени жены по мужу по наиболее продуктивной модели (Войтенко 2015: 14). Семейства могли получать прозвище по имени предка, от которого пошла очередная ветвь родства. Например, в деревне есть дом Па́вликовых - 'от имени Павла Конова, отца семейства'. Семейное прозвище Tácuны дети - 'от имени Татьяны Дмитриевны, которую нынешнее старшее 
поколение в детстве называли баба-Та́ся', исчезло, поскольку все дочери бабыTácu вышли замуж и главой семейства стал Егор Егорович Бу́хов, а всех его членов стали называть Буховы. Семья, заселяющая крайний с восточной стороны деревни дом, получила прозвище Пограни́чники - 'живущие на том конце'. Авторы прозвища проживают на западной половине деревни, являющейся центром, поскольку именно тут проходят все посиделки, а также находится дом старосты. В ста метрах к западу от деревни по той же дороге стоит дом семьи Мдинара́дзе, приехавшей сюда несколько десятков лет назад, но уже получившей основательно закрепившееся за ней склоняемое прозвище Ва́сисуба́ни - 'по несклоняемому названию грузинского сорта вина Вазисубани'. По этническому признаку могли даваться и личные прозвища. Так по воспоминаниям одной из респонденток в д. Ивановская жила Ню́рка-Мордо́вка - 'по происхождению мордва'.

Личным прозвищем могло стать имя родственника. Так Александра Конова называли Гриша́к - 'по внешней схожести со своим дядей-Гришей'. Дядю-Гришу в свою очередь звали Гре́ком - 'производное от Григорий'. Неоднозначно трактуется происхождение женского прозвища Лёль-Саню́ха. По одной из версий компонент Лёль - 'сокращенно от Елена, по имени сестры'. Однако в речи респондентки зафиксирована в отношении к другому человеку номинация лёльДу́ня, имеющая сходный компонент, в данном конкретном случае семантизируемая как 'няня'. По зафиксированным воспоминаниям, у лёль-Дуни не было своих детей, поэтому она присматривала за чужими, среди которых и возникло такое прозвище. Являются ли эти компоненты омонимами или же один из них с течением времени приобрел в сознании носителей иную этимологию, неизвестно.

Прозвища нередко получали тезки. Однажды во время какого-то праздника, когда собрались гости, за столом оказалось три Валерия: Печа́льный - 'когда пил, становился грустным', Валерка-дли́нный - 'за высокий рост' и Валерка-сре́дний'потому что был третьим и нуждался в каком-то прозвании'. Последнее не имело активного употребления и было дано ради шутки. Сосед Павла Кузьмича, ставшего родоначальником Па́вликовых, Павел Савельевич имел прозвище Пан ‘за то, что был богат, зажиточен и брал людей в наем'. В связи с этим бытует предание о зарытом на его участке кладе, однако все поиски новых хозяев остались безуспешны.

Внешность тоже могла стать мотивирующим признаком. Так Каранда́m получил свое прозвище, потому что 'был маленьким и худым’, а Толстомя́сый ‘толстым и ленивым'. Отпрыск Песковых Валентин был прозван Монахом 'за 
длинную бороду’. Личные качества также становились причиной номинации. Так в отношении местного понятия ча́морный - 'человек со странностями', наблюдается переход из апеллятивной лексики в онимическую (Сызранова 2013: $25)$, если речь идет о конкретном человеке, обладающим данным признаком.

Для ряда номинаций, таких как Гомьірь, Котёл и Роди́мый не удалось установить мотивирующий признак.

В речи жителей д. Стенинская активно представлены зоофорные антропонимы (Подольская 1978: 60), не встречавшиеся в д. Лешниково. Местного охотника Александра Виноградова называли Змей, потому что 'он ходил на охоту по змеиной тропе', т. е. через непролазные места. Соседку респондетки тетю Валю звали Блохо́й - 'за въедливый характер', про нее также говорили: «кусаешь как блоха». Школьного товарища Владимира Мышляева за поведенческие особенности называли Чúma, а также Чúma-Чúma, потому что 'он был как обезьяна'. Таким образом мы наблюдаем переход зоонима в антропоним. Зафиксированы воспоминания о случае, иллюстрирующем отношение некоторых жителей к зоофорным прозвищам в прошлом веке: «А у нас вот, Виноградовых, тех, дядь-сашиных он (отец, дядя-Саша) сам прозвал: Юру - Кара́сиком, а Нину Плотва́. И вот мы пришли, маме рассказываем, Кара́сик, там, Плотва́... А она и говорит: какой Кара́сик? Какая тебе тут Плотва́? Всех крестили при рождении, давали при крещении имена. И чтобы называли всех по именам! Мне даже не говорите, чтобы я не слышала от вас этого». Хотя на фоне общей картины такое неприятие прозвищ является скорее исключением.

Встречаются здесь и незоофорные антропонимы. Так, например, Валерия Кузьмина называли Чума́, поскольку он 'переболел менингитом, поле чего стал срывистым и драчливым'.

Объем собранного материала демонстрирует факт активного бытования прозвищ в речи жителей Дубровского прихода на протяжении нескольких поколений и вплоть до наших времен. Процесс народного ономастического творчества продолжается и по сей день. Возникающие ономастические единицы имеют разный круг использования: одни бытуют в речи небольших групп людей, другие же становятся известны всем жителям деревни и даже далеко за ее пределами, на всем пространстве Дубровского прихода. При этом самими носителями этот процесс не осознается, и на вопрос «есть ли у вас здесь какие-то прозвища» чаще всего следует отрицательный ответ. Однако стоит вывести разговор на непринужденную тему, как сразу же открывается кладезь народной творческой мысли. Данная работа демонстрирует богатство неисследованной 
лексики, требующей тщательного изучения не только в этом регионе, но и в масштабах всей Московской области.

В ходе исследования было зафиксировано 30 антропо-ономастических единиц, в частности: 6 семейных прозвищ и 24 личных. Среди них 24 являются однокомпонентными, а 6 - двукомпонентными. Установить мотивирующий признак удалось для 25 единиц из 30 собранных. Опираясь на семантику мотивирующего признака, полученные лексемы мы классифицируем следующим образом: по фамилии - 4 единицы, по имени предка - 3 единицы, трансформация личного имени -3 , по внешнему признаку -4 единицы, по поведенческой черте - 7 единиц, по национальной принадлежности - 2 единицы, по месту проживания - 1 единица, ситуативная - 1 единица. Из общего числа также можно выделить группу из 5 зоофорных лексем, в основе которых лежат разные мотивирующие признаки.

\section{Summary}

According to the 2019 expedition, family nicknames, as well as personal ones, are actively represented in the speech of the villagers of Leshnikovo. A motivating sign was set for several nicknames. In the village of Steninskaya zoomorphic nicknames are actively used, but there are others. Based on the collected material, it can be concluded that the creativity of anthroponymic onomastics in the folk environment of this region is an integral part of village life.

\section{Литература}

Войтенко, А. В. Прозвищные имена в речи подмосковных диалектоносителей. In: Русский язык и литература: история и современность (вып. II). Сборник научных статей по материалам докладов и сообщений конференции, посвященной 75-летнему юбилею профессора Л. Ф. Копосова. Москва: МГОУ, 2015.

Давыдов, Н. В. Шатурский край при царе Михаиле Федоровиче в письмах и мерах кн. В. П. Кропоткина. Москва: Известия, 2010.

Казаков, В. М. Дозорная книга. История шатурских деревень. Москва: Издательство журнала «Москва», 1995.

Подольская, Н. В. Словарь русской ономастической терминологии. Москва: Наука, 1978. 
Григорий МАРКАДЕЕВ

Ономастика деревень Дубровского прихода Кривандинского сельского поселения

Сызранова, Г. Ю. Ономастика: учебное пособие. Тольятти: Издательство ТГУ, 2013.

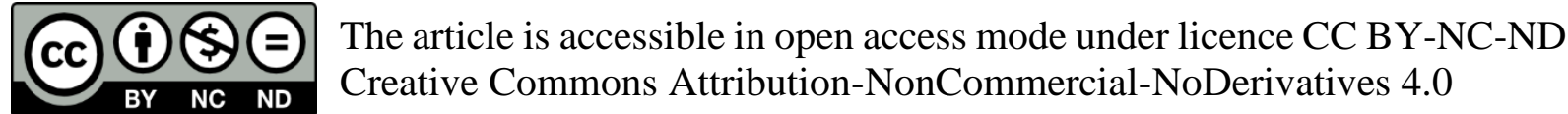

